\title{
Production Performances of Indonesian Native Rooster (Gallus gallus domesticus) Supplemented with Germinated Mung Bean Sprouts and Acidifiers in the Diet
}

\author{
Nonok Supartini ${ }^{1}$, Muhammad N. Ihsan ${ }^{2 *}$, Muhammad H. Natsir ${ }^{2}$, and Nurul Isnaini ${ }^{2}$ \\ ${ }^{1}$ Animal Science Department, Tribhuwana Tuggadewi University, Malang, 65144, Indonesia \\ ${ }^{2}$ Faculty of Animal Science, University of Brawijaya, Malang, 65145, Indonesia \\ *Corresponding author's Email: m_nur_ihsan@ub.ac.id; ORCID: 0000-0002-1069-3125
}

Received: 06 Jul. 2020

Accepted: 25 Aug. 2020

\begin{abstract}
The research aimed to analyze the production performances of the Indonesian native rooster (Gallus gallus domesticus) fed germinated mung bean sprouts and acidifier supplementation in the diet. A total of 24 roosters aged 12 months with an average body weight of $2.29 \pm 0.23 \mathrm{~kg}$ were used for the research subject. The diet was composed of a basic diet supplemented with 48-hours germinated mung bean sprouts and acidifier, with a basic no supplement diet as a control group. The research was conducted as an in vivo factorial randomized block design with different amounts of germinated mung bean sprouts $(0 \%$ and $1.8 \%)$ and acidifiers $(0 \%, 0.4 \%, 0.80 \%$, and $1.20 \%)$ as the research treatment. Each treatment was performed in triplicate, and the observed production performances include Daily Intake (DI) of feed, Feed Consumption Ratio (FCR), Average Daily Gain (ADG), and Body Weight (BW). All data were analyzed using ANOVA (analysis of variance) and then tested by Tukey's test to determine significant differences. The results showed that the supplementation of mung bean sprouts and acidifiers did not give any differences from DI, FCR, ADG, and BW of Gallus gallus domesticus. However, the supplementation of germinated mung bean sprouts and acidifiers in the present research showed better overall production performances compared to the control group. The best production performance of the treatments was found at $1.8 \%$ germinated mung bean sprout and $1.2 \%$ acidifier additive based on the FCR $(1.14 \pm 0.06)$ with DI at $91.94 \pm 1.11 \mathrm{gram}(\mathrm{g}) / \mathrm{head}$, ADG at $305.33 \pm 34.93 \mathrm{~g} / \mathrm{day}$, and final BW found after 30 days at 2,434.67 $\pm 155.28 \mathrm{~g}$. It has been concluded that the germinated mung bean sprout and acidifiers supplementation increases the production performance of Gallus gallus domesticus, with longer and higher supplement levels being suggested.
\end{abstract}

Key words: Mung bean sprouts, Native chicken, Poultry diet, Production performances

\section{INTRODUCTION}

The feed diet provides a source of energy and nutrition required for poultry to live, grow, and reproduce well (Bell and Weaver, 2002). Mustafa et al., (2017) stated that the nutritional value in feed played an important role in determining production performance in poultry, which contributed up to $70 \%$ of production performances in native chickens. However, nutritional optimization value in native chicken feed was still underdeveloped due to the lower FCR compared to broiler chickens, even though the feed adaptability of native chickens would provide various approaches to feed optimization by using various alternative feed supplements (Henuk, 2013).

The important factors that to consider when choosing alternative feeds are that they are abundant, inexpensive, of good nutritional value and non-competitive for human consumption in order to achieve optimal native chickens farming (Ahmadani, 2015). One of the abundant and inexpensive alternative feedstuffs in Indonesia is the mung bean sprout (Purwono and Hartono, 2005). Mung bean sprouts are known to be high in protein and multiple vitamins, but they also contained nutritional inhibitory compounds that could be eliminated by certain treatments, such as submersion, germination, and heat. One of the nutritional inhibitors was trypsin inhibitor in the form of tannin or polyphenol, which suppresses protein digestibility. However, the nutritional inhibitory activity of the compound would be reduced during germination (Anggrahini, 2007). In the germination period, some starch content in the mung bean was metabolized into maltose, which was catalyzed by amylase enzyme (Huang et al., 2014), while the protein molecules were converted 
into amino acids. Research by Anggrahini (2007) revealed that mung bean sprout contained 24\% lysine, $19 \%$ threonine, $29 \%$ alanine, and $7 \%$ phenylalanine, several fatty acids, and minerals.

However, most dietary supplements contained synthetic compounds that could have adverse effects to the chickens (Iji and Tivey, 1998), such as microbial retention, while their residual compounds were also harmful to human health (Pavlovic et al., 2005). Also, the increased public concern about the emergence of antibiotic-resistant strains prompted the exploitation of alternate growth promoters for antibiotics (Yadav et al., 2016). Therefore, the use of natural feed additives was preferred to increase feed efficiency (Huang et al., 2014).

Few alternatives were available for feed additives, such as probiotics, prebiotics, phytochemicals, enzymes, and organic acids. Among these alternatives, the organic acids, also known as acidifiers, had become widely known as the compound played an important role in the intestinal health in animals (Natsir, 2008). The potential of acidifiers in the livestock feed industry has been known for decades for their preservative and nutritional properties (Partanen and Morz, 1999). Fernandez et al. (2006) stated that organic acids were cell metabolites with low toxicity and were beneficially used as feed additives. In addition, research by Soltan (2008) revealed that supplementing organic acid as a feed additive could effectively increase nutrient absorption. Rukmana (2003) added that using alternative feed supplements for native chickens should not only meet the energy and protein requirements but also be high in vitamin $\mathrm{E}$ to support the reproduction of the chickens. In the present research investigated the effect of germinated mung bean sprout supplement and acidifier on the production performance of Gallus gallus domesticus, a native breed of chicken spread on Indonesia and Malaysia.

\section{MATERIALS AND METHODS}

The research was conducted in vivo on 24 Gallus gallus domesticus at the age of 12 months with an average body weight of $2.29 \pm 0.23 \mathrm{~kg}$ obtained in Malang, Indonesia. The overall picture of Gallus gallus domesticus in the present research is shown in figure 1. The mung bean sprouts were germinated for 48 hours to be used as a dietary supplement along with an acidifier. The basal diet was formulated with yellow maize, bran meal, palm oil, meat bone meal, soybean meal and minerals. The acidifier used in this study consisted of fumaric acid, formic acid, propionic acid, citric, and lactic acid. Proximate analysis performed to examine the nutritional value of the feed, which included energy, crude protein, crude fats, crude fiber, calcium, and phosphor (Table 1).

The Gallus gallus domesticus in the present research was reared in a grouped pens model with the area off 100 $\times 170 \mathrm{~cm}$, each group containing three chickens. The pens were equipped with drinking and feeding gallons. The Gallus gallus domesticus was initially adapted with the basic feed for 10 days, gradually switched to the treatment diets for 6 days, and then fed completely with diet treatments of up to $100 \mathrm{~g} / \mathrm{head} / \mathrm{day}$ for 30 days. The present research treatments were basic feed with different additional amounts of germinated mung bean sprout $\left(\mathrm{K}_{0}=\right.$ $\left.0 \% ; \mathrm{K}_{1}=1.8 \%\right)$ and acidifiers $\left(\mathrm{A}_{0}=0.00 \% ; \mathrm{A}_{1}=0.40 \%\right.$; $\left.\mathrm{A}_{2}=0.80 \% ; \mathrm{A}_{3}=1.20 \%\right)$. Each treatment was performed in triplicate, and the observed production performances included feed Daily Intake (DI), Feed Consumption Ratio (FCR), Average Daily Gain (ADG), and Body Weight (BW). The research was designed in a factorial randomized design, and all data were analyzed using ANOVA, followed by Tukey's test to determine any significant differences.

Table 1. Nutrient compositions of research treatments

\begin{tabular}{lcccccccc}
\hline Nutrient composition & $\begin{array}{c}\text { A0K0 } \\
\text { control) }\end{array}$ & A0K1 & A1K0 & A1K1 & A2K0 & A2K1 & A3K0 & A3K1 \\
\hline Energy (kcal/kg) & 2809 & 2818 & 2802 & 2807 & 2800 & 2800 & 2798 & 2795 \\
Crude protein (\%) & 17.20 & 17.00 & 17.00 & 17.00 & 17.00 & 17.00 & 17.00 & 17.00 \\
Crude fats (\%) & 3.20 & 3.10 & 3.10 & 3.00 & 3.10 & 2.90 & 3.10 & 2.90 \\
Crude fiber (\%) & 4.40 & 4.40 & 4.40 & 4.40 & 4.30 & 4.40 & 4.30 & 4.40 \\
$\mathrm{Ca}(\%)$ & 0.90 & 0.90 & 0.90 & 8.00 & 0.80 & 0.80 & 0.70 & 0.70 \\
$\mathrm{P}(\%)$ & 0.50 & 0.40 & 0.40 & 0.40 & 0.40 & 0.40 & 0.40 & 0.40 \\
\hline
\end{tabular}

Description: A0K0 (control) $=0 \%$ mung bean sprout and $0 \%$ acidifiers; A0K1 $=1.8 \%$ mung bean sprout and $0 \%$ acidifiers; A1K0 $=0 \%$ mung bean sprout and $0.4 \%$ acidifiers; $\mathrm{A} 1 \mathrm{~K} 1=1.8 \%$ mung bean sprout and $0.4 \%$ acidifiers; $\mathrm{A} 2 \mathrm{~K} 0=0 \%$ mung bean sprout and $0.8 \%$ acidifiers; $\mathrm{A} 2 \mathrm{~K} 1=1.8 \%$ mung bean sprout and $0.8 \%$ acidifiers; $\mathrm{A} 3 \mathrm{~K} 0=0 \%$ mung bean sprout and $1.2 \%$ acidifiers; $\mathrm{A} 3 \mathrm{~K} 1=1.8 \%$ mung bean sprout and $1.2 \%$ acidifiers. 


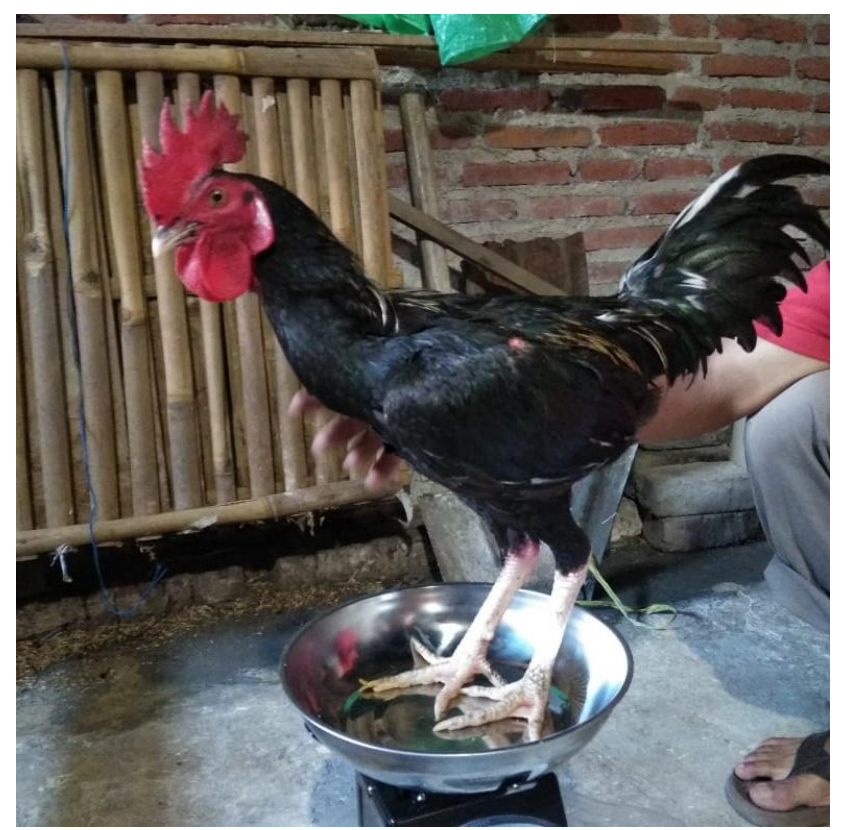

Figure 1. Gallus gallus domesticus used in present research

\section{RESULTS}

The proximate analysis was performed to examine the nutritional value of the basic feed (control/no supplement) as well as the research treatments. The result of the proximate analysis is presented in table 1.

The research data on feed consumption and feed conversion are presented in table 2 . These data revealed that germinated mung bean sprout and acidifiers supplementation could increase the DI and lower the FCR compared to the control group, even though the increase was not significant ( $p>0.05)$. Moreover, it can be seen that in $1.8 \%$ mung bean sprout and $1.2 \%$ acidifier additive (A3K1), the treatment showed the lowest FCR (1.14 \pm 0.06 ), which indicates the best feed efficiency.

The BW and ADG of Gallus gallus domesticus in the present study are presented in table 3 . The results revealed that the $\mathrm{BW}$ and $\mathrm{ADG}$ of Gallus gallus domesticus were increased along with germinated mung bean sprout. The highest BW and ADG in the present research were found for $\mathrm{A} 3 \mathrm{~K} 0$ and $\mathrm{A} 3 \mathrm{~K} 1$, respectively, with a total of mung bean sprout and acidifier supplementation showed better BW and ADG compared to the control group. The higher BW and ADG indicate that the mung bean sprout and acidifier supplement could provide better nutrient absorption, especially protein, which promotes tissue development, although note that the protein content of all treatments is relatively similar (Table 1).
Table 2. Daily feed consumption and feed conversion of the research data

\begin{tabular}{lcc}
\hline Treatments & Daily intake (g/head) & FCR \\
\hline A0K0 (Control) & $91.75 \pm 4.69$ & $1.16 \pm 0.06$ \\
A0K1 & $87.56 \pm 3.46$ & $1.23 \pm 0.13$ \\
A1K0 & $94.11 \pm 2.47$ & $1.17 \pm 0.11$ \\
A1K1 & $91.49 \pm 6.65$ & $1.17 \pm 0.15$ \\
A2K0 & $94.14 \pm 1.37$ & $1.22 \pm 0.03$ \\
A2K1 & $92.85 \pm 0.92$ & $1.22 \pm 0.03$ \\
A3K0 & $93.06 \pm 0,82$ & $1.15 \pm 0.10$ \\
A3K1 & $91.94 \pm 1.11$ & $1.14 \pm 0.06$ \\
\hline
\end{tabular}

Description: A0K0 (control) $=0 \%$ mung bean sprout and $0 \%$ acidifiers; $\mathrm{A} 0 \mathrm{~K} 1=1.8 \%$ mung bean sprout and $0 \%$ acidifiers; $\mathrm{A} 1 \mathrm{~K} 0=0 \%$ mung bean sprout and $0.4 \%$ acidifiers; $\mathrm{A} 1 \mathrm{~K} 1=1.8 \%$ mung bean sprout and $0.4 \%$ acidifiers; $\mathrm{A} 2 \mathrm{~K} 0=0 \%$ mung bean sprout and $0.8 \%$ acidifiers; $\mathrm{A} 2 \mathrm{~K} 1=1.8 \%$ mung bean sprout and $0.8 \%$ acidifiers; $\mathrm{A} 3 \mathrm{~K} 0=0 \%$ mung bean sprout and $1.2 \%$ acidifiers; $\mathrm{A} 3 \mathrm{~K} 1=1.8 \%$ mung bean sprout and $1.2 \%$ acidifiers.

Table 3. Bodyweight and average daily gain of the research data

\begin{tabular}{lcc}
\hline \multicolumn{1}{c}{ Treatments } & Bodyweight $(\mathbf{g})$ & $\begin{array}{c}\text { Average daily gain } \\
\text { (g/day) }\end{array}$ \\
\hline A0K0 (control) & $2.380 \pm 228.11$ & $170 \pm 65.38$ \\
A0K1 & $2.137 \pm 136.52$ & $275 \pm 34.79$ \\
A1K0 & $2.425 \pm 294.07$ & $260 \pm 65.19$ \\
A1K1 & $2.348 \pm 138.12$ & $284 \pm 115.68$ \\
A2K0 & $2.315 \pm 97.34$ & $228 \pm 12.12$ \\
A2K1 & $2.281 \pm 32.59$ & $259 \pm 45.13$ \\
A3K0 & $2.446 \pm 198.14$ & $219 \pm 26.08$ \\
A3K1 & $2.434 \pm 155.28$ & $305 \pm 34.93$
\end{tabular}

Description: A0K0 (control) $=0 \%$ mung bean sprout and $0 \%$ acidifiers; $\mathrm{A} 0 \mathrm{~K} 1=1.8 \%$ mung bean sprout and $0 \%$ acidifiers; $\mathrm{A} 1 \mathrm{~K} 0=0 \%$ mung bean sprout and $0.4 \%$ acidifiers; $\mathrm{A} 1 \mathrm{~K} 1=1.8 \%$ mung bean sprout and $0.4 \%$ acidifiers; $\mathrm{A} 2 \mathrm{~K} 0=0 \%$ mung bean sprout and $0.8 \%$ acidifiers; $\mathrm{A} 2 \mathrm{~K} 1=1.8 \%$ mung bean sprout and $0.8 \%$ acidifiers; $\mathrm{A} 3 \mathrm{~K} 0=0 \%$ mung bean sprout and $1.2 \%$ acidifiers; $\mathrm{A} 3 \mathrm{~K} 1=1.8 \%$ mung bean sprout and $1.2 \%$ acidifiers.

\section{DISCUSSION}

The increased DI with better FCR found in the present research was due to the rich vitamin content of the mung bean sprouts. Stephens (2018) stated that germinating of mung bean would increase the vitamin content, and after two days of germination would reach the maximum vitamin content while improving the palatability, which directly affects the feed intake. Research by Troszynska et al. (2004) on the legume seeds germination also revealed that germination would improve the mung bean palatability. The palatability of feedstuffs is a response of 
the nervous and taste bud system towards the flavour experienced by the animal (Lamichchane et al., 2018), while Mansoub and Nezhady (2011) added that the nutritional value of the feed also had a positive response to feed intake.

In table 2 , it can be seen that $1.8 \%$ of mung bean sprout and $1.2 \%$ acidifier additive gave the best FCR. The FCR indicates the total amount of feed that is required to gain one kilogram of body weight, which indicates that supplementing both feeds could optimize the production performances of Gallus gallus domesticus. Lamichchane et al., (2018) stated that nutrients availability in feed plays a vital role in maintaining energy balance, promoting body growth, and immunity, as well as providing antioxidant and repairing damaged tissue. In addition to the mung bean sprouts, acidifiers also contributed to the production performances of the chickens. Brown and Southern (1985) explained that the citric acid content in the acidifier would provide the intestinal environment with a hydrogen ions donor, which helped maintain the $\mathrm{pH}$ of the intestinal lumen. The condition thus increases nutrient absorption in the animal intestine (Deepa et al., 2011). Similar results were also shown by Natsir (2008), that stated that acidifier supplementation in the diet could maintain digestive $\mathrm{pH}$, which is essential for the protein absorption of chickens.

Widodo (2002) mentioned that a higher nutrient absorption indicated better digestibility of the feed. The feed digestibility was then reflected in the FCR of the animal, with a lower FCR value indicating more efficient feed consumption (Rasyaf, 2006). Lacy and Vest (2000) stated that FCR was affected by several factors, such as genetic, feed quality, animal health, temperature, sanitation, ventilation, medication, and rearing management. The FCR is one of the indicators for determining the production performances, as it correlates within the BW and ADG of the animal (Rasyaf, 2006). The protein compounds in the feed are essential for chicken metabolism and body growth (Widodo, 2002). It is widely known that protein and energy, along with other micronutrients such as vitamins and minerals, are the main nutrients that affect chicken production performance. Research by Purwono and Hartono (2005) showed that mung bean contained several vitamins, such as niacin, riboflavin, and folic acid, which will be increased after germination.

The increased BW and ADG were also affected by acidifier supplementation, as Lückstädt and Mellor (2011) indicated that acidifiers play an important role in digestibility and nutrient absorption by maintaining the $\mathrm{pH}$ of the digestive system, which inhibits the growth of pathogenic bacteria, such as Escherichia coli and Salmonella species, which would negatively affect product performance. Even though the supplementation of germinated mung bean sprout and acidifier positively affect production performance, the insignificant difference between DI, FCR, BW, and ADG were found in the present research, which was due to nature of the chicken breed. Native roosters, such as Gallus gallus domesticus, are known to have slower body growth than broiler chickens. Although the nutritional quality is an important factor, the age and strain of chickens also play an important role in the production performance (Amrullah, 2004). The slower growth of Gallus gallus domesticus then suggests a higher and longer supplement of mung bean sprout and acidifier in Gallus gallus domesticus.

\section{CONCLUSION}

It was concluded that mung bean sprouts and acidifiers supplementation increase the production performances of Gallus gallus domesticus, although the supplement amounts in the present study did not indicate any significant differences. The best result was shown with $1.8 \%$ mung bean sprout and $1.2 \%$ acidifier additive, which had an FCR of $1.14 \pm 0.06$, a DI of $91.94 \pm 1.11 \mathrm{~g} / \mathrm{head}$, an ADG of $305.33 \pm 34.93 \mathrm{~g} / \mathrm{day}$, and a final $\mathrm{BW}$ after 30 days of $2,434.67 \pm 155.28 \mathrm{~g}$.

\section{DECLARATIONS}

\section{Competing interests}

The authors declare that they have no competing interests.

\section{Author's contributions}

Nonok Supartini and Muhammad Nur Ihsan designed the research. Nonok Supartini and Muhammad Halim Natsir performed the research and analyzed the data. Nonok Supartini wrote the manuscript. Muhammad Nur Ihsan, Muhammad Halim Natsir, and Nurul Isnaini participated in the revision of the manuscript. All authors have read and approved the final version of the manuscript.

\section{Acknowledgements}

The authors would like to acknowledge the assistance of Mr Aldyon Restu Azkarahman, colleagues, as well as special work by the technical staff. The authors also appreciate the rector and the dean of the Faculty of Animal Science, who gave them opportunities and 
Supartini et al., 2020

financial support for the research through Penelitian Hibah Guru Besar and Doktor Universitas Brawijaya Tahun 2019 program.

\section{REFERENCES}

Ahmadani R (2015). The weight of hatching eggs, the weight of hatched chicken and the hatching rate of semi-intensively reared local chicken in koto perambahan village in Kampar Timur district of Kampar regency. MSc Thesis. Universitas Islam Negeri Sultan Syarif Kasim Riau. Available at: http://repository.uinsuska.ac.id/6164/1/fm.pdf

Amrullah IK (2004). Laying Hen Nutrition, $3^{\text {rd }}$ Edition. Lembaga Satu Gunung Budi, Bogor, p. 50.

Anggrahini S (2007). Effect of germination time of $\alpha$-tocopherol and proximate compounds of mung bean sprouts (Phaseolus radiatus L.). Agritech, 27 (4): 152-157. DOI: https://doi.org/10.22146/agritech.9850

Bell DD and Weaver WD (2002). Commercial chicken meat and egg production, $5^{\text {th }}$ Edition. Springer Science and Business Media Incorporation, New York, pp. 187-198.

Brown DR and Southern LL (1985). Effect of citric and ascorbic acids on performance and intestinal $\mathrm{pH}$ of chicks. Poultry Science, 64 (7): 1399-1401. DOI: https://doi.org/10.3382/ps.0641399

Deepa C, Jeyanthi GP and Chandrasekaran D (2011). Effect of phytase and citric acid supplementation on the growth performance, phosphorus, calcium, and nitrogen retention on broiler chicks fed with low level of available phosphorus. Asian Journal of Poultry Science, 5 (1): 28-34. http://dx.doi.org/10.3923/ajpsaj.2011.28.34

Fernandez F, Garcia V, Madrid J, Orengo J, Catala P and Megias MD (2006). Effect of formic acid on performance, digestibility, intestinal histomorphology and plasma metabolite levels of broiler chickens. British Poultry Science, 47 (1): 50-56. https://doi.org/10.1080/00071660500475574

Henuk YL (2013). Benefits and problems of keeping native chickens in Indonesia. 11 ${ }^{\text {th }}$ World Conference on Animal Production, Beijing, China, 15-20 October 2013. Available at: http://www.chinaexhibition.com/Official ...

Huang X, Cai W, and Baojun X (2014). Kinetic changes of nutrients and antioxidant capacities of germinated soybean (Glycine max L.) and mung bean (Vigna radiata L.) with germination time. Food Chemistry, $\quad 143 \quad$ (2014): $\quad$ 268-276. DOI: https://doi.org/10.1016/j.foodchem.2013.07.080

Iji PA and Tivey DR (1998). Natural and synthetic oligosaccharides in broiler chicken diets. World's Poultry Science Journal, 54: 129-143. DOI: https://doi.org/10.1079/WPS19980010

Lacy M and Vest LR (2000). Improving Feed Conversion in Broiler: A Guide for Growers. Springer Science and Business Media Incorporation, New York, pp. 50-55.

Lamichhane U, Regmi S and Sah R (2018). Changes in palatability of poultry feed using garlic, ginger and their combination. Acta Scientific Agriculture, 2 (11): 68-72. Available at: https://actascientific.com/ASAG/pdf/ASAG-02-0227.pdf
Lückstädt C and Mellor S (2011). The use of organic acids in animal nutrition, with special focus on dietary potassium diformate under European and Austral-Asian conditions. Recent Advances in Animal Nutrition - Australia, 18: 123-130. Available at: https://pdfs.semanticscholar.org/2cea/dea378990adb1303b1aa092f2 4d16f748a83.pdf?_ga $=2.117269314 .598815196 .1598327502$ 351389577.1591847690

Mansoub NH and Nezhady M (2011). Effect of garlic, thyme and yoghurt compared to antibiotics on performance, immunity and some blood parameters of broiler chickens. The Indian Journal of Animal Sciences, 81 (12): 1197-1200. Available at: http://epubs.icar.org.in/ejournal/index.php/IJAnS/article/view/1332 $\underline{7}$

Mustafa, Dasrul MA, Yaman S, Wahyuni, and Sabri M (2017). Effect of fermented feed combination with multienzyme and vitamin $\mathrm{E}$ on Arabian chicken semen quality improvement. Journal of Agripet, 17 (1): 43-52. Available at: http://jurnal.unsyiah.ac.id/agripet/article/view/6576

Natsir MH (2008). The effect of using citric acid and lactic acid combination in liquid and encapsulated forms as a feed additive on carcass percentage and internal organ weights of broiler. Jurnal Ilmu dan Teknologi Hasil Ternak, 3 (2): 17-22. Available at: https://jitek.ub.ac.id/index.php/jitek/article/view/128/127

Partanen KH and Morz Z (1999). Organic acids for performance enhancement in pig diets. Nutrition Research Review, 12, 117-145. DOI: https://doi.org/10.1079/09544 2299108728884

Pavlovic V, Cekic S, Rankovic G, and Stoiljkovic N (2005). Antioxidant and pro-oxidant effect of ascorbic acid. Acta Medica Medianae, 44 (1): 65-69. Available at: https://link.springer.com/article/10.2478/s11536-010-0066-x

Purwono and Hartono R (2005). Green Bean, Penebar Swadaya Publishing, Jakarta, pp. 30-37.

Rasyaf M (2006). Native Chicken Handling, Penebar Swadaya Publishing, Jakarta, p. 55.

Rukmana R (2003). Native Chicken. Kanisius Publishing, Yogyakarta, p. 72.

Soltan MA (2008). Effect of dietary organic acid supplementation on egg production, egg quality and some blood serum parameters in laying hens. International Journal of Poultry Science, 7 (6): 613-621. DOI: http://dx.doi.org/10.3923/ijps.2008.613.621

Stephens JM (2018). Bean sprouts-Phaseolus aureus R. and Glycine max (L.) Merr. HS557, series of the Horticultural Sciences Department, UF/IFAS Extension. Original publication date April 1994. Revised August 2015. Reviewed in October 2018. Available at: https://edis.ifas.ufl.edu/mv024

Troszyńska A, Lamparski G and Kosińska A (2004). The sensory quality of sprouts obtained from the selected species of legume seeds. Czech Journal of Food Sciences, 22: 174-176. DOI: https://doi.org/10.17221/10652-CJFS

Widodo W (2002). Contextual Chicken Feed Nutrition. Universitas Muhammadiah Press, Malang, pp. 136-186.

Yadav AS, Kolluri G, Gopi M, Karthik K, Malik YS and Dhama K (2016). Exploring alternatives to antibiotics as health-promoting agents in poultry- a review. Journal of Experimental Biology and Agricultural Sciences, 4(3s): 368-383. DOI: https://doi.org/10.18006/2016.4(3S).368.383 